\title{
TITLE:
}

\section{A Golgi study on the habenular nucleus of the cat(Abstract_要旨 )}

$\operatorname{AUTHOR}(\mathrm{S})$ :

Iwahori, Nobuharu

\section{CITATION:}

Iwahori, Nobuharu. A Golgi study on the habenular nucleus of the cat. 京都大学, 1977, 医学博士

ISSUE DATE:

1977-01-24

URL:

http://hdl.handle.net/2433/221270

RIGHT: 


\section{【153】}

氏 名㟶堀焂明

学位の種類医学博士

学位記番号論 医 博 第 676 号

学位授与の日付 昭 和 52 年 1 月 24 日

学位授与の要件 学位規則第 5 条第 2 項該 当

学位論文題目 A Golgi study on the habenular nucleus of the cat

(Golgi 法によるネコの手綱核研究)

論文調查委員教授小川和朗教授亀山正邦教授水野昇

\section{論 文 内容 の 要 旨}

手綱核は大脳辺縁系と下位脳幹を結合する中継核の一つと見做され，その神経線維連絡関係より予想さ れる機能的重要さの故に, 従来多くの研究がなされてきた。しかしながら手綱核の線維連絡に関する諸家 の所見には多くの不一致点がみられる。これは，従来の研究が主として破壞実験に基づくもので西ったた め, 実験的損傷部を通過する神経線維の変性による所見と，実験的損傷部より括こる神経線維の変性所見

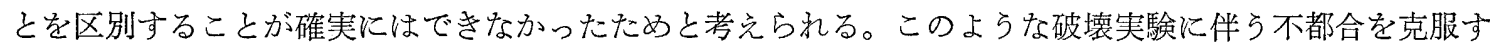
るため, 本研究では Golgi 法に上る手綱核の構造分析が試みら就た。

約 300 匹の仔ネコの脳をオスミウム酸と重クロム酸カリの混合溶液で固定し, 次いで硝酸銀溶液に浸し たのちセロイジン包埋して $100 \mu$ の連続切片を作成し，これをダンマール樹脂江入して封観察した。

手綱核は内側核と外側核に区分できる。内側核には， 2 種類の neuron が区別される。第 1 型は $12 \mu \times 18 \mu$ の梨状形の胞体を持つ neuron で，多くの spine を有する $2 \sim 5$ 本の一次樹状突起を出す。第 2 型は $14 \mu \times 23 \mu$ の紡錘形 neuron で $2 \sim 3$ 本の一次樹状突起を持つ。内側核の細胞はいずれも投射 neuron で その軸索は反屈束に入る。外側核には 4 種類の細胞が区別される。第 1 型は $27 \mu \times 43 \mu$ の多角形の胞体を むつ大型 neuron で $4 \sim 7$ 本の一次樹状突起を出す。第 2 型は外側核の主 neuron であり, 多くは卵円形 の胞体を持ち $4 \sim 6$ 本の一次樹状突起を出す。第 3 型は $15 \mu \times 25 \mu$ の小型の紡錘形の neuron で， $2 \sim 4$ 本の一次樹状突起を有する。以上 3 種類の neuron はいずれる投射 neuron でその軸索の大部分法反屈束 に入るが，その汸か手綱交連に入ると思われるものや，吻側深投射するものる少数存在する。第 4 型は所 謂 Golgi II 型でありその軸索は核内にの及分布する。15 $\mu$ 前后の不規則な形をした胞体より 4 〜 本の一 次樹状突起が出る。

内側核への求心性神経線維は視床髄条を通ってくるが，これに 2 種類が区別できる。一つは太い線維 で，䯣条の内側部を走ったのち腹方に曲って内側核に入り，多くの側枝を出して核内に終止する。他方は 細い線維である。これらの線維は両者とも内側核にのみ分布し外側核への終止は認められない。外側核へ 
の求心性神経線維には下行性, 上行性扣よび手綱交連よりのものが認められる。下行性求心線維は下視床 脚を通り，視床を通過して視床䯣条に入るものである。これらにはその太さによって 3 種類の線維が区別 できるが，そのいずれもが䯣条内を尾側に進みつつ外側核へ側枝を出す。下行性求心線維の大部分は外側 核に終止するが，一部は外側核に側枝を出したのちさらに手綱交連や反屈束に入る。上行性求心線維は反 屈束を上行し, 尾腹側方向より外側核に入るものである。これには太い線維と細い線維が区別され，乞の いずれもが大部分外側核に終止するが，一部は外側核を通り越してさらに吻側に進もものがある。手綱交 連よりの求心性線維は尾内側部より外側核に入り，その多くは外側核に終止するが，一部はさらに吻側に 進む。外側核への求心性線維はいずれも外側核内にのみ分布し，同時に内側核へも分布するものはない。 手綱核内には以上のような求心性線維のほか多くの通過性線維が認められる。それらは䯣条と手綱交連, または，髄条と反屈束の間を走るもので岁，上行性の線維も下行性の線維もともに存在すると思われ る。

以上の所見より，手綱核の内側核と外側核は互に隣接した核ではあるが，両者は細胞構築の面でも神経 線維連絡の面でも明らかに異なって㧍り，それぞれ別系統の神経連絡系に組又込をれていると考光られ る。

\section{論文審 查の結果の要旨}

本研究は大脳辺緑系の出力機序の形態的基礎を得ることを目的として括り, 大脳辺緑系と下位脳幹とを 結ぶ最も重要な中継核とされる手綱核について，その細胞構築と求心性・遠心性おるび内在性神経線維連 絡の詳細が Golgi 法の所見にもとづいて分析されている。

ニューロン連絡の形態学的研究は, 通常, 実験的損傷につついて扢こる神経線維の変性を追跡すること により行われるが，このよらな破壞実験では損傷部を通過する神経線維の変性所見と，損傷部に存在する 神経細胞より起始する神経線維の変性所見とを区別でさない。一方, 本研究で用いられた Golgi 法は, 現 在のところニューロンの全体像を得ることのできる唯一の方法とされながらも, その技術的困難さのため にニューロン連絡の研究に応用されることは希である。しかし，本研究ではこのよらな困難がよく克服さ れて和り，多くの正確な新知見が得られている。なかでも，ニューロンの全体像にもとづく手綱核細胞構 築と軸索側枝の分析は他の例を見ないものであり, 手綱核の作動機序について重要な示唆を与古ている。

よって，本論文は医学博士の学位論文として価值めるものと認める。 